\title{
Soil Fertility Status of Different Land Use System in Chikhaldhara tahasil of Maharashtra State
}

\author{
S.G. Zalte*, S.M. Bhoyar and P.W. Deshmukh \\ Department of Soil Science and Agricultural Chemistry, Dr. Panjabrao Deshmukh Krishi \\ Vidyapeeth, Akola (M.S.), India \\ *Corresponding author
}

\begin{tabular}{l} 
K e y w o r d s \\
$\begin{array}{l}\text { Soil survey, } \\
\text { Resources, Fertility, } \\
\text { Sustainable, } \\
\text { Melghat }\end{array}$ \\
\hline Article Info \\
\hline $\begin{array}{l}\text { Accepted: } \\
\text { xx October } 2018 \\
\text { Available Online: } \\
\text { xx November } 2018\end{array}$ \\
\hline
\end{tabular}

\section{A B S T R A C T}

A detailed soil survey was carried out at tribal area in Chikaldhara tahasil of Maharashtra state during the year 2015-2017. In present investigation data on natural resources such as soil fertility and present land use system aspect were generated studied and analysed. The study covered whole tribal area to identified different landform units to understand the soil heterogeneity as well as the present land use. Based on the visual observations Twenty (20) representative spot were selected for sampling and analysed for $\mathrm{pH}$, Electrical conductivity, Organic carbon, available Nitrogen, Phosphorous and Potassium and available Micro nutrient ( $\mathrm{Zn}, \mathrm{Mn}, \mathrm{Fe}$ and $\mathrm{Cu}$ ) by using standard analytical methods. Based on soil fertility status the $\mathrm{pH}$ of Chikhaldhara soils were slightly acidic to slightly alkaline in nature and organic carbon were low to medium. Nutritionally, soils in this high rainfall region showed lower content of available $\mathrm{N}$ and $\mathrm{P}$ and medium in available $\mathrm{K}$ however, medium to higher in available micronutrient status viz. Fe, $\mathrm{Mn}, \mathrm{Zn}$ and $\mathrm{Cu}$ Therefore there is need of proper land use according to capability of land by identifying the constraints for the production of available land. In order to use the land resources optimally on sustainable basis and also adaptation of management practice for increasing the fertility of soil.

\section{Introduction}

Land is the basic component of production systems and meets the basic requirement of all life on the earth. It is a natural resource providing most benefits to human kinds. However, it is a finite vital resource on whose proper use depend the life supporting systems of a country and socioeconomic development of the people (Sehgal, 1990). Maintaining, the present level of soil productivity and for meeting out the demand of the future, management of soil resources on scientific principles is very important. Therefore, increased emphasis is being laid on soil fertility and developing scientific criteria for land evaluation and interpretation of soils for multifarious land uses. At present productivity of the soil is observed to be reduced at a slow rate but in a continuous phase. Since the climatic attributes of the region are not changing at the faster rate, it is only the soil attributes which are causing reduction in the productivity. The low productivity might be due to the degradation of the land resource and also Imbalanced and inadequate use of 
chemical fertilizers, improper irrigation and various cultural practices also deplete the soil fertility rapidly (Medhe et al., 2012). Hence it is necessary to assess the fertility status of soil with the consideration of available nutrients status of soil, proper planning for increasing the productivity of area.

\section{Materials and Methods}

The field study was carried out in the Chikaldara tahasil of Maharashtra under Dr. Panjabrao Deshmukh Krishi Vidhyapeeth, Akola. The Chikhaldara lies between $21^{\circ} 13^{\prime}$ and $21^{\circ} .21^{\prime}$ North latitudes and $77^{\circ} 43^{\prime}$ and $77^{\circ} .72^{\prime}$ 'East longitudes. This region boasts of thick forests spread over the Satpura mountain range. The forest has predominantly teak and bamboo. The taluka headquarters of Chikhaldara is a famous hill station that maintains a cool temperature even in the hot summers and also it is at an altitude with highest vairat point $1188 \mathrm{mts}$.The major natural vegetation of the area in general comprises dry deciduous mixed tree species, some grasses and shrubs species (Fig. 1).

The commonly observed tree species are teak (Tectona grandis), palas, (Butea monosperma), ber (Ziziphus jujuba), khair (Acacia catechu), neem (Azadirata indica), babul (Acacia arabica), mango (Mangifera indica), mahua (Madhuca lalifolia) and Subabul (Leucaena leucocephala). The major crops grown in the kharif season are soybean (Glycine max), sorghum (Sorghum bicolor), pigean pea (Cajanus cajan), groundnut (Arachis hypogea), maize (Zea maize), green gram (Vigna sinesis) and kutki and also seasame etc. in some area. The main rabi season crops of the area are wheat (Triticum aestivum) and gram (Cicer aritium) grown under irrigation or stored moisture. In summer season where irrigation is more available the crop like moog and groundnut are grown in some area.
This area is also known as Melghat region, which is located in the physiographic unit i.e. eroded valley with the elevation of $320-1188$ meters above mean sea level. Korku is the dominant tribes inhabited in this forest region and have small land holding adjoining to forest. This toposheets was used as base map for location of sample sites area, ground truth sites and planning for traverse routes in the tribal field area of Chikhaldara tahasil and on the bases of the visual observations Twenty (20) representative spot were selected on different land use system based on single crop, double crop, scrubland, forest land and fallow land in area for details soil profile study (Table 1). The horizon wise samples were collected for their analysis of soil fertility parameter. The soil $\mathrm{pH}$ and EC was determined in soil suspension (1:2.5 soil: water) by using glass electrode $\mathrm{pH}$ meter (Richards, 1954). The soil sample was sieve through 100 mesh sieve for estimating organic carbon by Walkley and Black method.

The available Nitrogen was determined by alkaline potassium permanganate method as described by Subbaiah and Asija (1956) and available phosphorus was estimated colorimetrically as per the method given by Jackson (1967). Available potassium was extracted from the soil by using neutral normal ammonium acetate solution. DTPAextractant $(0.005 \mathrm{M}$ Dietylene triamine penta acetic, $0.01 \mathrm{~m} \mathrm{CaCl}_{2}+0.1 \mathrm{~N}$ triethanolamine at $\mathrm{pH}$ 7.3) were used for extracting exchangeable iron, copper, manganese and zinc. The concentration of micronutrients in the extract was determined by using Atomic Absorption Spectrophotometer, as outlined by Lindsay and Norwell (1978).

\section{Results and Discussion}

\section{Physio-chemical properties of soils}

Soil $\mathrm{pH}$ is very important physio-chemical properties of soil, which influence availability 
of plant nutrients, microbial activity and plant growth. The measure of the chemical reaction of the soil is expressed by its $\mathrm{pH}$ value. The soil $\mathrm{pH}$ is mostly related to the parent material, climates and topography position which determine soil composition.

Soils of Chikhaldara tahasil were slightly acidic to slightly alkaline in nature, the $\mathrm{pH}$ values ranging from 5.74 to 8.57 . In general it was observed that, $\mathrm{pH}$ of surface soils is lower as compared to subsurface and increases with depth of the pedon except pedon no. 15, which was only pedon showed higher alkalinity, may be due to higher exchangeable sodium content in the lower soil layers. Pedon $\mathrm{P}_{5}$ was slightly acidic in reaction had $\mathrm{pH}$ range from 5.74 to 5.99 might be due to heavy rainfall at higher topography in the Melghat region which leads to mineral dissolution and exchange of $\mathrm{H}^{+}$and releases $\mathrm{Ca}, \mathrm{Mg}, \mathrm{Na}$ and $\mathrm{K}$ ions in soil solution.

These basic cations are leached and subject to erosion with water more rapidly. Furthermore, it was observed that, subsurface soil of pedon $\mathrm{P}_{15}$ moderately alkaline and $\mathrm{pH}$ range from 8.10 to 8.31 may be due to accumulation of soluble salts. Adelbert Kharlyngdoh et al., (2015) reported that, the $\mathrm{pH}$ of the soils of the micro-watershed varied from 4.15 to 5.91 i.e. slightly acidic to extremely acidic in reaction and increased with depth which was mainly due to leaching of bases downwards. Most of the pedon $\mathrm{P}_{1}, \mathrm{P}_{2}, \mathrm{P}_{3}, \mathrm{P}_{4}, \mathrm{P}_{7}, \mathrm{P}_{8}, \mathrm{P}_{9}, \mathrm{P}_{10}, \mathrm{P}_{11}$, $\mathrm{P}_{12}, \mathrm{P}_{13}, \mathrm{P}_{14}, \mathrm{P}_{16}, \mathrm{P}_{17}, \mathrm{P}_{19}$ and $\mathrm{P}_{20}$ were neutral in soil reaction, which is best suited for most of the crops.

Soil electrical conductivity (EC) is a measure of the amount of salts in soil. It is an important indicator of soil health. It affects crop yields, crop suitability, plant nutrient availability and activity of soil microorganisms. Excess salts hinder plant growth by affecting the soil-water balance. Salt levels can increase as a result of cropping, irrigation and land management practices. The data present in table 2 revealed that, the Electrical Conductivity of the Chikhaldara tahasil soils were less than 1 $\mathrm{dSm}^{-1}$, soils are considered non-saline and do not impact most crops and soil microbial processes. In general soils were low in EC which was ranges from 0.07 to $0.46 \mathrm{dSm}^{-1}$. The lower values of the EC in Chikhaldara tahasil may be due to the fact that, the hilly area receives high rainfall with leads to high runoff of water from high elevation to low elevation which also washed away the dissolved salts in it.

The organic carbon is an indication of organic fractions in soils formed due to microbial decomposition of residues. The presence of organic matter in soil is a symbol of life in soil. It contains, retains and supplies all essential plants nutrients and influence the fertility of soil. It was observed that, the organic carbon content in surface soils of Chikhaldhara tahasil was varied from 0.36 to 1.01 per cent, which indicated that soils were medium to high in organic carbon content. In general organic carbon content in soils decreases as depth of the soils increased. The minimum organic carbon in soils was observed in pedon $\mathrm{P}_{12}$ which was 0.36 per cent in upper soils and decreased up to 0.15 per cent in lower levels of the soils. However, maximum organic carbon was observed in pedon $\mathrm{P}_{20}$ of fallow land cover with grasses vegetation, which was highest 1.01 per cent in surface soils and reduced up to 0.86 per cent in lower soil layers. Relatively higher organic carbon content in soil under forest and fallow land as compared to cultivated land, which may be due to the addition of organic matter through continuous leaf fall and undisturbed condition of the forest land. Most of pedon showed organic carbon decrease with increase in depth, which is mainly due to accumulation of plant residues in the surface. Similar also reported by Sarkar et al., (2001). 
Table.1 Geo-referencing of soils pedons selected for study area

\begin{tabular}{|c|c|c|c|c|c|c|}
\hline $\begin{array}{l}\text { Sr. } \\
\text { No. }\end{array}$ & $\begin{array}{l}\text { Land use } \\
\text { system }\end{array}$ & Pedon & $\begin{array}{l}\text { Name of } \\
\text { Village }\end{array}$ & Latitude & Longitude & $\begin{array}{c}\text { MSL } \\
\text { (Meter) }\end{array}$ \\
\hline 1) & \multirow{8}{*}{$\begin{array}{c}\text { Single } \\
\text { cropping } \\
\text { system }\end{array}$} & $\mathbf{P}_{1}$ & Sawarya & $21^{0} 25.982$ & $77^{0} 01.992$ & 387 \\
\hline 2) & & $\mathbf{P}_{2}$ & Aadhao & $21^{0} 25.690$ & $77^{0} 05.861$ & 424 \\
\hline 3) & & $\mathbf{P}_{3}$ & Korda & $21^{0} 136.086$ & $77^{0} 31.222$ & 838 \\
\hline 4) & & $\mathbf{P}_{4}$ & Chunkhadi & $21^{0} 34.486$ & $77^{0} 25.068$ & 759 \\
\hline 5) & & $\mathbf{P}_{5}$ & Makhala & $21^{0} 31.981$ & $77^{0} 22.912$ & 948 \\
\hline 6) & & $\mathbf{P}_{6}$ & Motha & $21^{0} 24.104$ & $77^{0} 22.337$ & 1031 \\
\hline 7) & & $\mathbf{P}_{7}$ & Hirdamal & $21^{0} 38.183$ & $77^{0} 31.566$ & 604 \\
\hline 8) & & $\mathbf{P}_{8}$ & Telkhar & $21^{0} 19.173$ & $77^{0} 20.322$ & 582 \\
\hline 9) & \multirow{7}{*}{$\begin{array}{l}\text { Double } \\
\text { cropping } \\
\text { system }\end{array}$} & $\mathbf{P}_{9}$ & Beriteki & $21^{0} 26.360$ & $77^{0} 00.310$ & 379 \\
\hline 10) & & $\mathbf{P}_{10}$ & Katkum & $21^{0} 34.095$ & $77^{0} 32.734$ & 850 \\
\hline 11) & & $\mathbf{P}_{11}$ & Churni & $21^{0} 37.508$ & $77^{0} 30.956$ & 771 \\
\hline 12) & & $\mathbf{P}_{12}$ & Aaladoh & $21^{0} 23.927$ & $77^{0} 20.509$ & 1077 \\
\hline 13) & & $\mathbf{P}_{13}$ & Badnapur & $21^{0} 21.186$ & $77^{0} 22.317$ & 550 \\
\hline 14) & & $\mathbf{P}_{14}$ & Dharmdhao & $21^{0} 18.269$ & $77^{0} 18.319$ & 522 \\
\hline 15) & & $\mathbf{P}_{15}$ & Tembhursonda & $21^{0} 18.646$ & $77^{0} 18.616$ & 537 \\
\hline 16) & \multirow{2}{*}{$\begin{array}{c}\text { Forest } \\
\text { land }\end{array}$} & $\mathbf{P}_{16}$ & Dhakna & $21^{0} 25.531$ & $77^{0} 03.825$ & 402 \\
\hline 17) & & $\mathbf{P}_{17}$ & Katkali & $21^{0} 15.357$ & $77^{0} 03.662$ & 612 \\
\hline 18) & \multirow{2}{*}{$\begin{array}{c}\text { Scrub } \\
\text { land }\end{array}$} & $\mathbf{P}_{18}$ & Madki & $21^{0} 39.553$ & $77^{0} 38.074$ & 978 \\
\hline 19) & & $\mathbf{P}_{19}$ & Jambli & $21^{0} 19.906$ & $77^{0} 15.028$ & 639 \\
\hline 20) & $\begin{array}{c}\text { fallow } \\
\text { land }\end{array}$ & $\mathbf{P}_{20}$ & Gullarghat & $21^{0} 15.625$ & $77^{0} 01.326$ & 642 \\
\hline
\end{tabular}


Table.2 Physio-chemical properties of soil in Chikhaldara tahasil

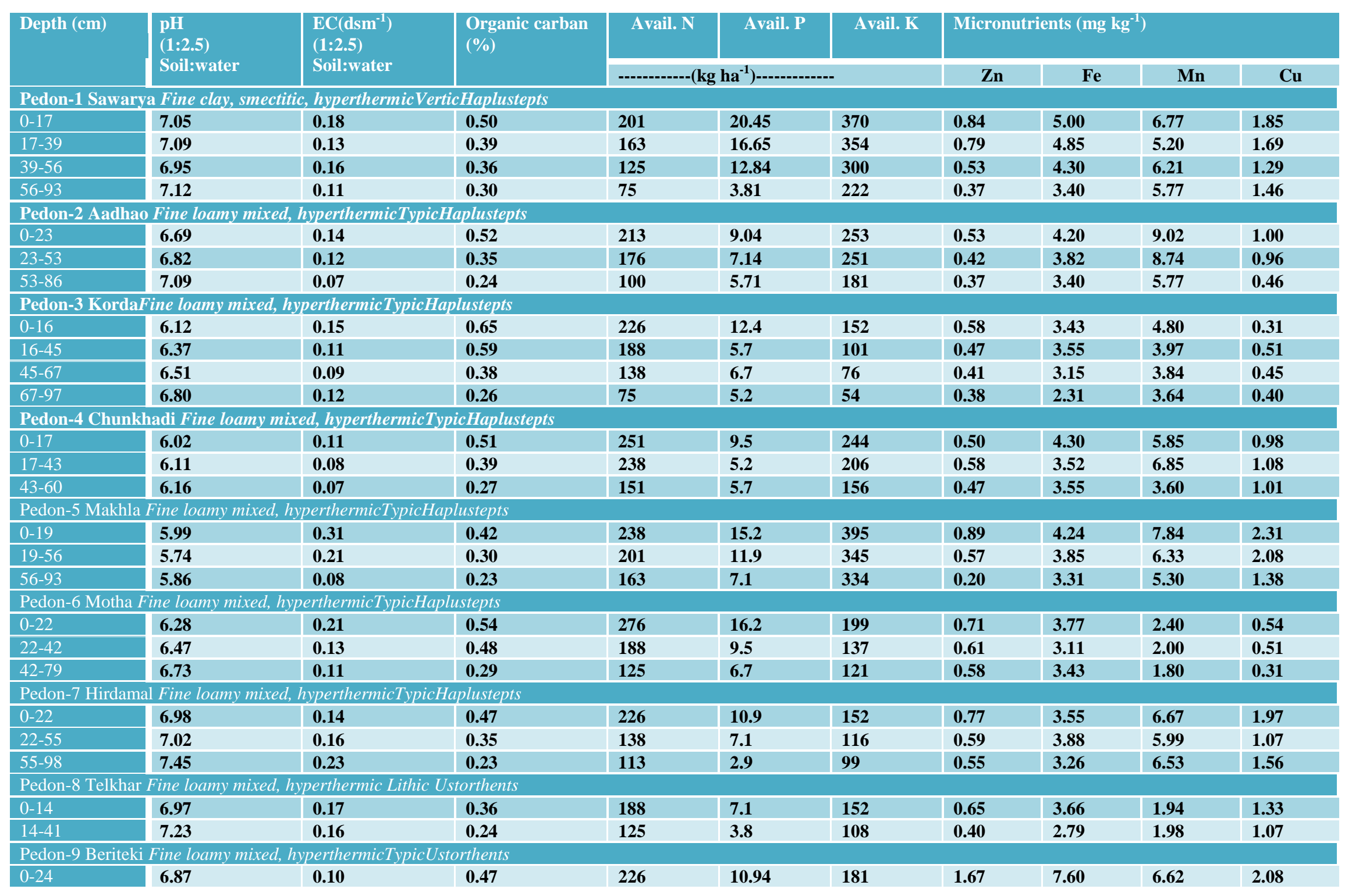


Int.J.Curr.Microbiol.App.Sci (2018) 7(11): 2219-2228

\begin{tabular}{|c|c|c|c|c|c|c|c|c|c|c|}
\hline $24-55$ & 7.10 & 0.10 & 0.41 & 163 & 5.23 & 116 & 1.10 & 5.28 & 6.14 & 1.36 \\
\hline \multicolumn{11}{|c|}{ Pedon-10 Katkhumb Fine loamy mixed, hyperthermic Lithic Ustorthents } \\
\hline $0-23$ & 7.10 & 0.27 & 0.57 & 125 & 15.70 & 110 & 0.58 & 4.22 & 5.56 & 0.66 \\
\hline $23-49$ & 7.21 & 0.15 & 0.36 & 138 & 7.61 & 94 & 0.21 & 3.15 & 3.64 & 0.40 \\
\hline \multicolumn{11}{|c|}{ Pedon-11 Churni Fine loamy mixed, hyperthermicTypicHaplustepts } \\
\hline $0-18$ & 7.18 & 0.20 & 0.56 & 188 & 10.9 & 123 & 0.87 & 4.38 & 6.94 & 0.99 \\
\hline $18-52$ & 7.26 & 0.16 & 0.48 & 151 & 5.7 & 88 & 0.72 & 3.82 & 4.99 & 0.78 \\
\hline $52-89$ & 7.50 & 0.15 & 0.36 & 88 & 3.8 & 56 & 0.53 & 2.64 & 3.71 & 0.97 \\
\hline \multicolumn{11}{|c|}{ Pedon-12 Alladoh Fine loamy mixed, hyperthermicTypicUstorthents } \\
\hline $0-11$ & 7.53 & 0.35 & 0.36 & 226 & 15.2 & 338 & 0.87 & 3.70 & 6.53 & 3.37 \\
\hline $11-33$ & 7.40 & 0.27 & 0.27 & 151 & 11.4 & 278 & 0.55 & 2.70 & 5.30 & 1.56 \\
\hline \multicolumn{11}{|c|}{ Pedon-13 Badnapur Fine loamy mixed, hyperthermic Lithic Ustorthents } \\
\hline $0-22$ & 7.68 & 0.21 & 0.66 & 151 & 11.9 & 143 & 0.78 & 2.31 & 0.99 & 0.97 \\
\hline $22-52$ & 7.74 & 0.23 & 0.40 & 113 & 3.3 & 121 & 0.49 & 2.57 & 1.06 & 1.47 \\
\hline \multicolumn{11}{|c|}{ Pedon-14 Dharmdho Fine loamy mixed, hyperthermic Lithic Ustorthents } \\
\hline $0-16$ & 7.15 & 0.11 & 0.40 & 163 & 6.2 & 262 & 0.35 & 5.27 & 2.20 & 0.89 \\
\hline $16-27$ & 7.32 & 0.07 & 0.17 & 88 & 4.8 & 181 & 0.31 & 5.13 & 2.00 & 0.73 \\
\hline \multicolumn{11}{|c|}{ Pedon-15 Tembursonda Fine clay, smectitic, hyperthermicTypicHaplusterts } \\
\hline $0-19$ & 8.31 & 0.26 & 0.48 & 238 & 6.7 & 170 & 0.76 & 3.55 & 1.94 & 1.01 \\
\hline $19-29$ & 8.10 & 0.35 & 0.29 & 163 & 2.9 & 148 & 0.60 & 3.06 & 1.96 & 0.90 \\
\hline $29-49$ & 8.12 & 0.29 & 0.20 & 100 & 1.4 & 110 & 0.51 & 1.93 & 1.92 & 0.87 \\
\hline $49-72$ & 8.13 & 0.40 & 0.18 & 75 & 4.3 & 139 & 0.38 & 2.31 & 3.64 & 0.40 \\
\hline \multicolumn{11}{|c|}{ Pedon-16 Dhakna Fine clay mixed, hyperthermicTypicHaplustepts } \\
\hline $0-10$ & 6.71 & 0.15 & 0.61 & 213 & 9.51 & 188 & 0.89 & 4.24 & 7.84 & 1.56 \\
\hline $10-37$ & 6.88 & 0.09 & 0.45 & 188 & 6.66 & 161 & 0.57 & 3.85 & 6.33 & 2.08 \\
\hline $37-63$ & 6.97 & 0.10 & 0.32 & 151 & 3.81 & 139 & 0.20 & 3.31 & 5.30 & 2.38 \\
\hline \multicolumn{11}{|c|}{ Pedon-17 Katkhali Fine loamy mixed, hyperthermic Lithic Ustorthents } \\
\hline $0-19$ & 6.87 & 0.13 & 0.83 & 213 & 7.61 & 217 & 0.48 & 7.82 & 4.90 & 1.15 \\
\hline \multicolumn{11}{|c|}{ Pedon-18 Madki Fine loamy mixed, hyperthermicTypicHaplustepts } \\
\hline $0-21$ & 7.23 & 0.11 & 0.44 & 201 & 12.4 & 246 & 0.77 & 3.55 & 6.67 & 1.97 \\
\hline $21-44$ & 7.31 & 0.46 & 0.36 & 151 & 8.6 & 222 & 0.58 & 3.52 & 5.85 & 1.08 \\
\hline 44-76 & 7.66 & 0.24 & 0.29 & 100 & 5.2 & 152 & 0.55 & 3.26 & 5.53 & 0.58 \\
\hline 76-104 & 7.88 & 0.22 & 0.24 & 75 & 4.3 & 139 & 0.38 & 2.31 & 3.64 & 0.40 \\
\hline \multicolumn{11}{|c|}{ Pedon-19 Jambli Fine loamy mixed, hyperthermicTypicHaplustepts } \\
\hline $0-21$ & 6.39 & 0.16 & 0.44 & 188 & 9.5 & 190 & 0.16 & 3.98 & 2.17 & 0.79 \\
\hline 21-37 & 6.49 & 0.15 & 0.35 & 138 & 7.6 & 150 & 0.21 & 3.33 & 2.00 & 0.73 \\
\hline $\begin{array}{l}37-69 \\
\end{array}$ & 7.17 & 0.20 & 0.21 & 88 & 5.7 & 121 & 0.22 & 3.17 & 1.90 & 0.51 \\
\hline \multicolumn{11}{|c|}{ Pedon-20 Gullarghat Fine loamy mixed, hyperthermic Lithic Ustorthents } \\
\hline $0-17$ & 7.04 & 0.18 & 1.01 & 251 & 19.50 & 244 & 0.91 & 4.10 & 5.36 & 1.78 \\
\hline $17-43$ & 7.19 & 0.12 & 0.86 & 238 & 15.22 & 204 & 0.81 & 3.76 & 4.62 & 1.40 \\
\hline
\end{tabular}


Fig.1 Soil profile location map of study area in Chikhaldara tahasil

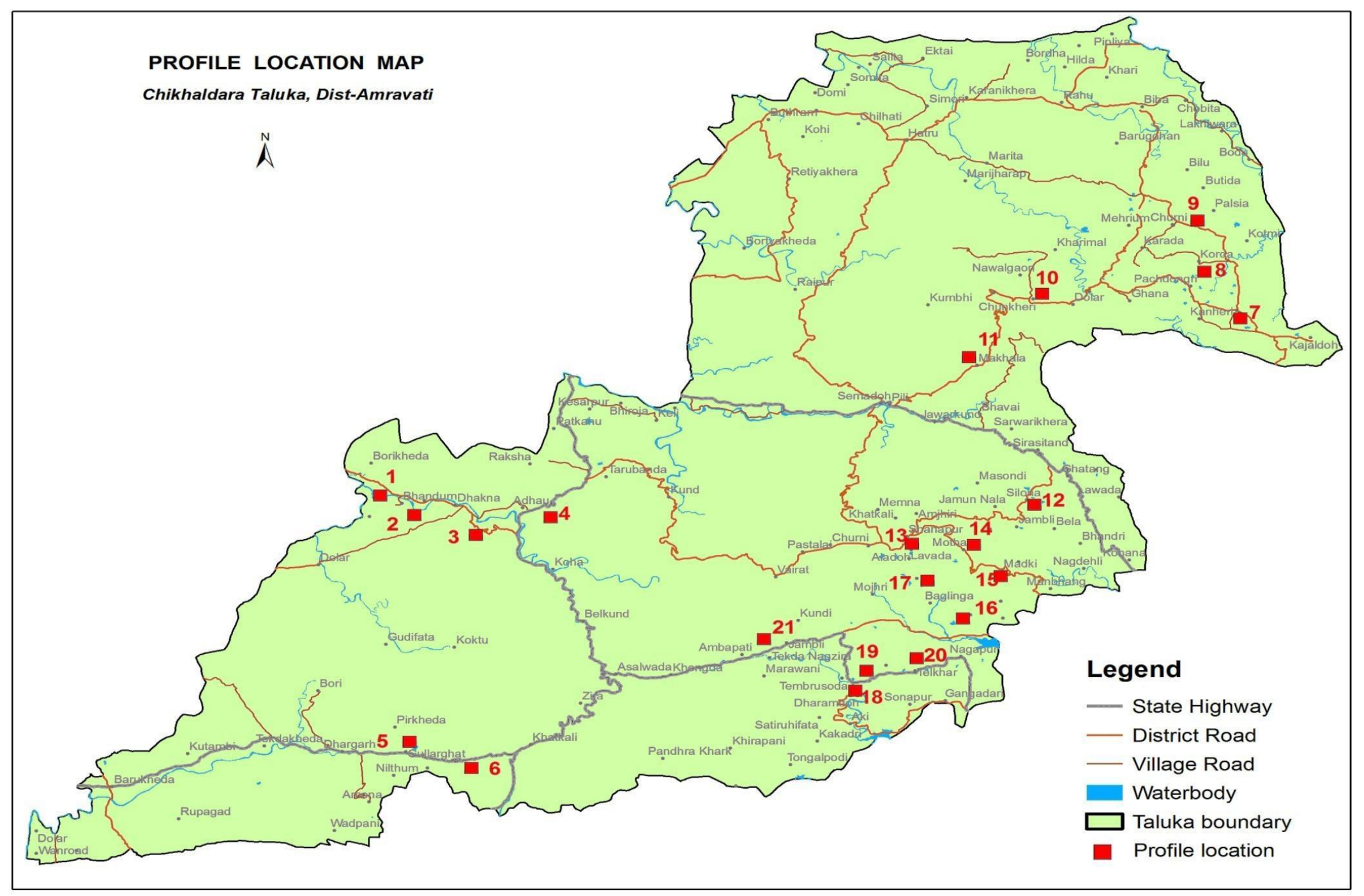


Nasre et al., (2013) also reported that the lowest organic carbon content $\left(4.2 \mathrm{~g} \mathrm{~kg}^{-1}\right)$ was observed in surface soils occurring on foot slopes and alluvial plain, whereas, the soils occurring on escarpments with forest cover showed the highest organic carbon content $\left(28.7 \mathrm{~g} \mathrm{~kg}^{-1}\right)$.

\section{Nutrient status of soils}

Available macro and micro nutrients horizon wise in pedon are discussed and presented in table 2 .

Nitrogen is the most vital major nutrient required by plants for proper growth and development. Nitrogen contents in surface soil of Chikhaldara tahasil range from $125 \mathrm{~kg}$ $\mathrm{ha}^{-1}$ to $276 \mathrm{~kg} \mathrm{ha}^{-1}$. The data revealed that, lowest average $\mathrm{N}$ content $125 \mathrm{~kg} \mathrm{ha}^{-1}$ was observed in pedon $\mathrm{P}_{10}$. Whereas, the highest average $\mathrm{N}$ content was noticed in pedon $\mathrm{P}_{6}$ $276 \mathrm{~kg} \mathrm{ha}^{-1}$. The available nitrogen was higher in surface soils as compared to subsoil layers. This might be due to the higher content of organic carbon in surface soils. Similar results were also reported by Todmal et al., (2008). In general, the soils were low in available nitrogen content. The variation in available nitrogen content in soils could be attributed to the differences in their physiographic as well as the differential cultivation and management of these soils

Phosphorus is the second most important major nutrient required by plants after nitrogen for proper growth and development. Phosphorus content in soils of Chikhaldhara tahasil was varied between $6.2 \mathrm{~kg} \mathrm{ha}^{-1}$ and $20.45 \mathrm{~kg} \mathrm{ha}^{-1}$ in surface soil layer. It was observed from the data that phosphorus content was lowest $6.2 \mathrm{~kg} \mathrm{ha}^{-1}$ in pedon $\mathrm{P}_{14}$ and highest $20.45 \mathrm{~kg} \mathrm{ha}^{-1}$ in pedon $\mathrm{P}_{1}$. Higher phosphorus content in soils of pediment and valley may be attributed to higher clay content in these soils and the declined trend of phosphorus with depth may due to higher fixation of available $P$ by clay. Similar findings were also reported by Todmal et al., (2008). The phosphorus content is seen to be increasing with reduction in slope and elevation, indicating higher phosphorus content in soils of pediment and valley which may also be attributed to higher clay content in these soils. Low available phosphorus content of these soils could be attributed to their high fixing capacity which prevents phosphorus to come into readily available form in the soil solution.

Potassium is the third important major nutrient required by plants for their proper growth and development after nitrogen and phosphorus. Available potassium content in soils of Chikhaldhara tahasil varied from 110 $\mathrm{kg} \mathrm{ha}^{-1}$ to $395 \mathrm{~kg} \mathrm{ha}^{-1}$. The potassium content also increased with the clay content. This may be attributed to the K-rich minerals occurring in the soil (Pal, 1984) and the relative immobility of this element on account of fixation by clay. Most of the surface soils had higher available potassium content which might be due to more intense weathering of potash bearing minerals, generation of leaf litter from different crops in cropping systems, release of labile $\mathrm{K}$ from organic residues, application of $\mathrm{K}$ fertilizers and upward translocation of $\mathrm{K}$ from lower depth with capillary rise of ground water (Patil et al., 2008).

The assessment of soil resource for micronutrient contents, as precise as possible would be much advantageous to planners, extension workers, fertilizer dealers and to individual farmers. The results revealed that, available $\mathrm{Cu}, \mathrm{Fe}, \mathrm{Zn}$ and $\mathrm{Mn}$ contents vary from 0.31 to $3.37 \mathrm{mg} \mathrm{kg}^{-1}, 2.31$ to $7.60 \mathrm{mg}$ $\mathrm{kg}^{-1}, 0.16$ to $1.67 \mathrm{mg} \mathrm{kg}^{-1}$ and 0.99 to $9.02 \mathrm{mg}$ $\mathrm{kg}^{-1}$, respectively in surface soils. The data indicate that the average contents of all micronutrients are highest in pedon $\mathrm{P}_{15}$ which 
may be attributed to higher clay and organic matter content in these soils. An increasing content of micronutrient was observed with increasing the fineness of texture and organic carbon. Similar findings were also reported by Gajbhiye et al., (1993) on shallow to deep black soils of Maharashtra. In general, the decreasing trend of these micronutrients content was observed in all the soils, which might be due to decreasing trend of organic carbon and may be because of manures and fertilizers application to the surface soils.

Thus, from the present investigation it can be concluded that, being a hilly region developed on basalt, land was sloppy and undulating. Soil depth was varied from shallow to medium $\mathrm{cm}$. In an average, soils were free from soluble salt hazards with neutral $\mathrm{pH}$. Nutritionally, soils in this high rainfall region showed lower content of available $\mathrm{N}$ and $\mathrm{P}$ and medium in available $\mathrm{K}$ however, medium to higher in available micronutrient status viz. $\mathrm{Fe}, \mathrm{Mn}, \mathrm{Zn}$ and $\mathrm{Cu}$. The situation therefore demands the need of appropriate management practices in order to increase the soil fertility status by adopting many such practices as nutrient management, increased use of organic nutrient sources, sustainable land use and cropping systems, and appropriate agronomic practices.

\section{References}

Adelbert Kharlyngdoh, Carolyn Zothansiami, P. K. Bora, P. T. Das, B. U. Choudhury and A. K. Singh, 2015. Characterization and Classification of Soils in Eastern Himalayan Agro-climatic Region: A Case Study in Nongpoh Microwatershed of Ri-Bhoi District, Meghalaya. Journal of the Indian Society of Soil Science, Vol. 63 (1): 2429.
Jackson, M. L. 1973. Soil Chemical Analysis. Prentice Hall of India Pvt. Ltd. New Delhi.

Lindsay, W. L. and W.A Norwel, 1978. Development of DTPA soil test for zinc, iron, manganese and copper. Soil Sci. Soc. Am. J, vol 42:421-428.

Medhe, S. R., Tankankhar V. G., Salve A.N., 2012. Correlation of chemical properties, secondary nutrients and micronutrient anions from the soils of Chakur Tahsil of Latur district, Maharashrta. Journal of Trends in life sciences, 2012, 1(2).

Nasre, R. A, M. S. S. Nagaraju, Rajeev Srivastava, A. K. Maji and A. K. Barthwal, 2013. Characterization, Classification and Evaluation of Soils of Karanji Watershed, Yavatmal District of Maharashtra for Land Resource Management using Geospatial Technologies. Journal of the Indian Society of Soil Science, Vol. 61(4): 275286.

Pal, D. K., S. Nath and S. K. Banerjee, 1984. Characteristics of some forest soils of Darjeeling Himalayan Region. Journal of the Indian Society of Soil Science 32: 716-724.

Patil, G. D., V. R. Khedkar, A. S. Tathe and A. N. Deshpande, 2008. Characterization and classification of soils of agricultural college Farm, Pune. J. Maharashtra agric. Univ. 33 (2):143148.

Richards, L. A., 1954, Diagnosis of improvement of salines and alkali soils, USDA Handbook No. 60, USDA Washington D.C.126: 657-662.

Sehgal, J. L., 1990. Soil resource mapping of India and its application for land use planning, NBSS Publ.25, NBSS \& LUP (ICAR), Nagpur, Maharashtra.

Soil Survey Staff, 1998. Keys to Soil Taxonomy Eight Edition, National 
Resource Conservation Centre USDA, Blacksburg, Virginia.

Subbiah, B. V. and G. L. Asija, 1956. A rapid procedure for estimation of available nitrogen in soils. Curr. Sci. 25: 259-260.

Todmal, S.M., Patil B.P., Tamboli B.D. Characterisation and classification of soils in Agriculture College Farm,
Kolhapur. J Maharashtra agric. Univ. 2008; 33(3): 287-291.

Walkley, A and I. A. Black 1934. An examination of the Dogjareff method for determining soil organic matter and a proposed modification of the chromic acid titration method. Soil Science 37: 29-33.

\section{How to cite this article:}

Zalte, S.G., S.M. Bhoyar and Deshmukh, P.W. 2018. Soil Fertility Status of Different Land Use System in Chikhaldhara tahasil of Maharashtra State. Int.J.Curr.Microbiol.App.Sci. 7(11): 2219-2228. doi: https://doi.org/10.20546/ijcmas.2018.711.248 